\title{
What Once Was Old Is New Again
}

\author{
Barbara A. Hotelling, WHNP-BC, CD(DONA), LCCE
}

\begin{abstract}
Through seminars and continuing educational opportunities, recently certified Lamaze childbirth educators beginning their teaching careers have learned of the changes in birth practices over the past 50 years. However, they may not have heard the personal stories about the locations and conditions in which Lamaze educators first taught. In this column, five childbirth educators share their memories of the birthing climate, teaching strategies, class populations, and other aspects of Lamaze childbirth education 50 years ago and how the "old ways" compare with today's classes. Their stories not only provide an important, historical perspective to build on the past and improve future educational opportunities for expectant women and their families but also illustrate Lamaze's ongoing efforts to promote natural, safe, and healthy birth practices.
\end{abstract}

The Journal of Perinatal Education, 19(3), 68-72, doi: 10.1624/105812410X514468

Keywords: childbirth education, childbirth education trends, history of childbirth education, Lamaze International

This year, as Lamaze International celebrates five decades of providing childbirth and parenting education, we look back to see how far we have come. Have we made a difference in the way women give birth? Are new parents empowered by their birth experiences to take on the challenges of parenting? How do childbirth education classes several decades ago differ from today's classes?

Recently, I asked five Lamaze childbirth educators to recall what classes and educational approaches were like when they first began teaching and to compare their early classes with the classes we teach today. A few common themes emerged from their accounts, and some delightful stories were retold. So, sit comfortably in your favorite furniture, enjoy your favorite beverage, and delight in the following stories shared by Eugene Declercq, Judith Lothian, Sigrid Nelsson-Ryan, Penny Simkin, and Ann Tumblin.

\section{HOME CLASSES \\ Eugene Declercq:}

When I started teaching, we were looking to buy our first house. One of the criteria was a living room large enough for six pregnant women and their partners to be on the floor working on their relaxation exercises over the 7 weeks of classes. A far cry from current weekend classes taught in a hospital.

\section{CLASSES AS SOCIAL NETWORKS Judith Lothian:}

What I really loved about classes in the beginning, from 1973 and on: small groups. For me, it was neighborhood women-the same gals I met in the park with my own small children. I can't count the number of students who actually became lifelong friends. We teachers got to know each other well, too. Caroline Donahue (current Chair of Lamaze International's Education Council) and I met 
doing Lamaze and are still friends, 35-plus years later!

I loved that everyone wanted to have a natural birth. And I loved that they really weren't so afraid. Mostly, they were afraid the hospital or doctor would interfere-what else is new? But it was so much easier to talk a doctor into doing something different-being more hands off. At least some of them were pretty easy to get on our side.

In those early days of teaching natural childbirth, we only knew to relax and breathe, but it worked! And we also spent so much time talking about the wonder and the joy of giving birth. In retrospect, it seemed so straightforward. Are we making it too complicated today? Too much information? We didn't worry about cesarean-the rate was $6 \%$. We didn't worry about breech-everyone did breech deliveries, unless labor was long and difficult. No one induced. You waited until you went into labor. In the early 1970s, there were no fetal monitors, no routine use of intravenous lines. We were fighting episiotomy and enemas! But it was so much simpler. The bad part: no midwives, no birthing centers, no home births in New York City. But, oh, the joy of having your couples have happy, wonderful, transforming births! They almost all did!

I think we need to start doing those small, homebased classes again-but now early in pregnancy and moving straight through. I think we need to do that in order to build the relationships we had back then.

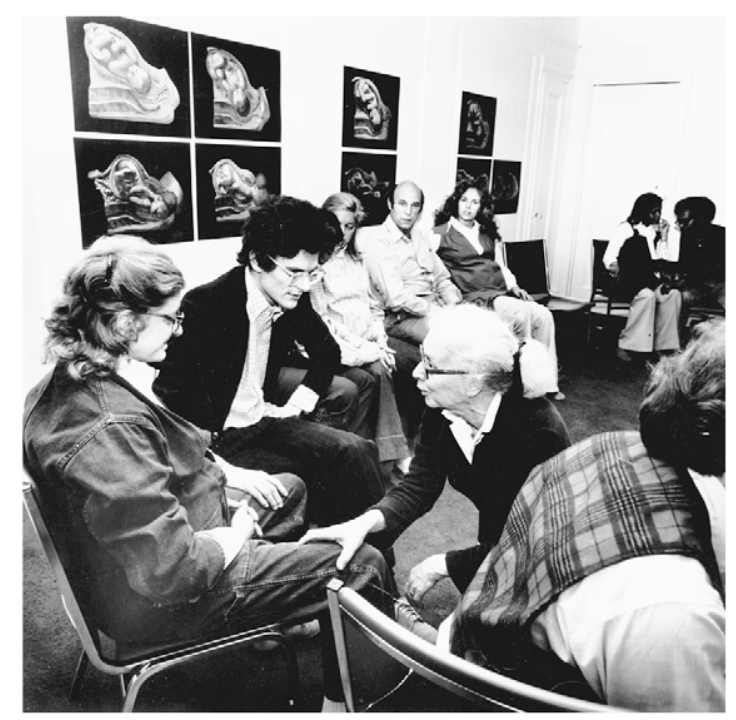

Elisabeth Bing, co-founder of the American Society for Psychoprophylaxis in Obstetrics (now, Lamaze International), in her New York City studio, teaching a natural childbirth education class in 1978.

\section{Ann Tumblin:}

One thing that I miss from earlier classes is the community spirit that develops in the classes and continues afterwards. Weekly mother- and baby-group meetings, play groups, and family get-togethers were more common in those early classes. I am attempting to regenerate that community spirit via the use of new technology - using the Internet. Each week, I send out a message that focuses on information and websites. Then, I encourage my students to stay in contact after their babies are born. One group whose babies are now crawling set up a Yahoo! group, and they are still e-mailing and sending pictures and planning another reunion. They have supported each other by communicating on the Internet.

\section{BALANCING HOME, WORK, AND CHILDBIRTH CLASSES Sigrid Nelsson-Ryan:}

Yes, I had some interesting moments. I was a member of the American Federation of Television and Radio Artists as well as a registered nurse. I was sought after to read scripts for accuracy (they didn't listen much to my critique), and they always needed a nurse when there were babies on the set. On both All My Children and One Life To Live (two popular soap operas on television), I was the nurse both in the filmed action as well as in "protecting" the baby from "exploitation" on the set. I remember I objected to a fully clothed preemie in an incubator, but relented when they undressed the awful looking doll. I also had a recurring role as Nurse Nelson on One Life to Live.

As long as One Life to Live was only a half hour, I had no trouble getting home in time to teach my Lamaze class. But when they went to an hour show and we occasionally had to reshoot a scene, I had to give up acting on television or teaching Lamaze. I chose to teach Lamaze in the 1980s.

At that time, I became a consultant to the Century Birthing Chair. It came on the scene at the same time that the Borning Bed and birthing room concept were developed. I observed over 100 births (on three continents) in the birthing chair. Those women loved the chair, when used correctly, getting in and out at will. Unfortunately, most doctors at the time didn't understand the concept of using gravity, of squatting, or of upright birth and preferred their controlled use of a delivery table. And the doctors and midwives who understood didn't need to have any special birthing chair for most of their clients. Any 
bed, floor, or tub worked just as well assisting women to give birth. But that chair was awfully comfortable.

One funny aside: My two little boys at home asked me, as we watched TV at home, "Mommy, how can you be both there and here?" They occasionally came on the set accompanied by their Swedish cousin who lived with us as an pair.

\section{MEN IN CHILDBIRTH EDUCATION}

\section{Eugene Declercq:}

I obviously also dealt with being a male educator, but that became less of an issue over time. When I began teaching in a local hospital, the director of childbirth education classes would steer couples with a "reluctant partner" to me.

\section{Penny Simkin:}

I began teaching in 1968, when almost everyone came for natural childbirth preparation. The class that I observed during my training was the last one taught at the YWCA, who underwrote the SACE (Seattle Association for Childbirth Education) classes until the organization was financially able to make it on its own. It was during the day of "for women only," but we had two evening classes to which the "husbands" (no unmarried partners or female companions) came. There, we went over some basic information about labor and a few ways to help if they were there for part of labor. Many husbands in our classes planned to attend the labor, birth, or both. It was still controversial at the time; in fact, it was the hot issue in childbirth reform at that time. Husbands who wanted to be there were considered by the general public as crazy or even perverted.

\section{TEACHING STYLES AND CONTENT Sigrid Nelsson-Ryan:}

My own teaching was always action oriented. I taught subjects with simultaneous practice. From the earliest times, I knew that couples who had put in a whole day at work were easily put to sleep by lecturing. So I didn't let them sleep in class. The only way to accomplish that was having them on their feet slow dancing while practicing breathing techniques or on the floor busy massaging each other and practicing back-massage skills. We drew faces on brown sandwich bags, writing on it what to bring to the hospital. That was one thing that changed as we reviewed the breathing techniques in the mid 1970s; there was very little chance of hy- perventilation while using slower breathing techniques.

We utilized concentration, rhythm, and relaxation instead of speed. I also started using children's songs and nursery rhymes as a guide to breathing rhythmically. Rhythm also had a calming influence in labor. As the years progressed, I also changed from words such as "husband" or "coach" to "labor partner."

\section{Penny Simkin:}

Pierre Vellay (successor to Fernand Lamaze), Elisabeth Bing, and Robert Bradley were the big names in natural childbirth. There were lots of arguments on whether abdominal breathing or chest breathing was best. Hot rivalry existed between Lamaze and Bradley disciples.

I taught the first class for couples after we left the YWCA in 1968. The cesarean rate was about $6 \%$, nationwide. Mid-forceps and even a few highforceps were used. Few vacuum extractions were being done, and those were by "European-trained doctors." Vaginal breech births were common, though with a saddle block.

Pudendal blocks were considered an okay part of natural birth, as were episiotomies. Inductions were done with buccal Pitocin (a tablet placed between cheek and gum), where it dissolved and released Pitocin. Daylight births became a goal to strive for.

Episiotomies were routine, usually mid-line, though there was considerable debate in the literature between mid-line and medio-lateral episiotomies (no argument on whether they were necessary!).

Salt restriction was practiced, and I taught about hidden salt in foods. Also, we taught how to put on support hose in the mornings before getting out of bed (before ankles swelled) to reduce swelling.

Weight gain was limited to 15 lbs to 20 lbs by most doctors, and gaining weight was a huge stressor for pregnant women, who were made to feel slovenly if they had gained too much weight. Weight-gain restrictions were lifted by the American College of Obstetricians and Gynecologists and others in the early 1970s, and quality of diet rather than weight gain was emphasized. (Now, we're back to restricting weight gain).

Home birth was almost unheard of, as were midwives, who only could work in places and with women that doctors didn't want to care for (Appalachia, migrant workers, and poor people in the Deep South and inner cities). 


\begin{tabular}{|c|c|}
\hline Lamaze Childbirth Education Then & Lamaze Childbirth Education Now \\
\hline Popular books: & pular books: \\
\hline $\begin{array}{l}\text { - Thank You, Dr. Lamaze by Marjorie Karmel } \\
\text { - Spiritual Midwifery by Ina May Gaskin }\end{array}$ & $t$ to Expect series by Heidi Murkoff \\
\hline Opportunities to view/observe birth: & Opportunities to view/observe birth: \\
\hline - None or few & DVDs \\
\hline & A Baby Story and Maternity Ward \\
\hline Class environment a & ucture: \\
\hline home & ital \\
\hline ools: homemade posters and supplies & aching tools: products from Childbirth Graphics ${ }^{\circledR}$ \\
\hline $\begin{array}{l}\text { - Handouts/Course design produced on typewriter; no readily } \\
\text { accessible copy machines }\end{array}$ & $\begin{array}{l}\text { - Handouts/Course design produced on computer; extra copies } \\
\text { easily printed or shared via e-mail/Internet }\end{array}$ \\
\hline $\begin{array}{l}\text { - Class rosters handwritten and copies made with } \\
\text { carbon paper }\end{array}$ & $\begin{array}{l}\text { - Class rosters produced on computer, using Microsoft Excel } \\
\text { program }\end{array}$ \\
\hline es & re compact classes \\
\hline $\begin{array}{l}\text { - Focus on breathing (“Hee-hee-hoo”) and relaxation } \\
\text { techniques }\end{array}$ & Еосис 0 \\
\hline - Covers-everything class & $\begin{array}{l}\text { - Several classes covering a variety of topics (e.g., breastfeeding, } \\
\text { postpartum, etc.) }\end{array}$ \\
\hline $\begin{array}{l}\text { - Class participants who advocated for themselves } \\
\text { and others }\end{array}$ & - Class participants who focus more on self \\
\hline Teaching ce & Teaching certification: \\
\hline $\begin{array}{l}\text { - American Society for Psychoprophylaxis in Obstetrics } \\
\text { (ASPO): ASPO Certified Childbirth Educator (ACCE) }\end{array}$ & rnational. I amazertified Childhirth Educator \\
\hline $\begin{array}{l}\text { - One year of provisional certification; educators were also } \\
\text { required to attend the births of three couples from } \\
\text { their classes }\end{array}$ & $\begin{array}{l}\text { - Successful completion of the National Organization for } \\
\text { Competency Assurance (NOCA) exam }\end{array}$ \\
\hline Birth interventions/procedures: & Birth interventions/procedures: \\
\hline pudendal blocks & - Epidurals \\
\hline - Breech vaginal birth & - Breech cesarean surgery \\
\hline & - $32.3 \%$ \\
\hline Labor/Birth & Labor/Birth support: \\
\hline $\begin{array}{l}\text { - If lucky (i.e., if the hospital allowed it), fathers were } \\
\text { permitted to attend labor and birth }\end{array}$ & $\begin{array}{l}\text { - Fathers, partners, doulas, and maybe more/maybe fewer } \\
\text { support persons are allowed to attend labor and birth }\end{array}$ \\
\hline Hospital birth environment: & Hospital birth environment: \\
\hline $\begin{array}{l}\text { - Mothers had to move from labor room to delivery room } \\
\text { to recovery room to postpartum room }\end{array}$ & $\begin{array}{l}\text { - LDRP (Labor-Delivery-Recovery-Postpartum) rooms are available, } \\
\text { allowing all activities to take place in one, private room }\end{array}$ \\
\hline - No/Few opportunities for breastfeeding support & - Lactation consultants on staff \\
\hline Comments made to mothers: & Comments made to mothers: \\
\hline - "Are you crazy taking Lamaze classes? Why suffer?" & - “Are you crazy taking Lamaze classes? Why suffer?" \\
\hline
\end{tabular}

\section{Ann Tumblin:}

Now I teach another generation of women. When I began teaching in 1978, the families who came to classes were committed to birthing unmedicated. Today's class participants often want to just learn about what will happen in the hospital. They are surprised to learn much more and even bend their philosophies some. It's challenging, but rewarding when they share how much they have enjoyed the classes.

History repeats itself. I remember when induction was used so much and gradually earlier and earlier that some babies went to intensive care nurseries. Then elective inductions were stopped, and some mothers went to 44 weeks. Can anyone see a repeat in history here?

\section{CHILDBIRTH EDUCATORS AS EARLY DOULAS}

\section{Sigrid Nelsson-Ryan:}

I used to go with any couple or mother who wished my presence in labor from my early years of teaching in 1969. I learned so much from observing my couples in labor, changing my teaching in subtle ways. Today, I encourage first-time mothers or women preparing for vaginal birth after cesarean to hire a doula. I introduce the concept early, explaining that it is hard 
for a first-time father to understand what he is seeing. The doula's greatest contribution is attending early labor to prevent mothers from going to the hospital prematurely. In my early teaching, I tried to fill that role by having couples call me in early labor to describe their symptoms and listening to the mothers' speech and breathing patterns.

\section{CONCLUSION}

We are often encouraged to revisit the past in order to avoid repeating our mistakes. Lamaze has always been an evidence-based organization working for the health and safety of mothers, infants, and families. Yet we remain an icon of structured breathing. The stories presented in this article demonstrate compassion, dedication, and ingenuity by earlier Lamaze educators in the United States. We invite international and other national Lamaze members with the same history of these qualities to send their stories to The Journal of Perinatal Education so that the archives of Lamaze education can be more complete.

BARBARA A. HOTELLING is Perinatal Nurse Coordinator for the Maternal and Child Health program and a nurse practitioner at the Department of Family Medicine of the University of North Carolina School of Medicine in Chapel Hill. She has served as President of Lamaze International, President of DONA International, and Chair of the Coalition for Improving Maternity Services.

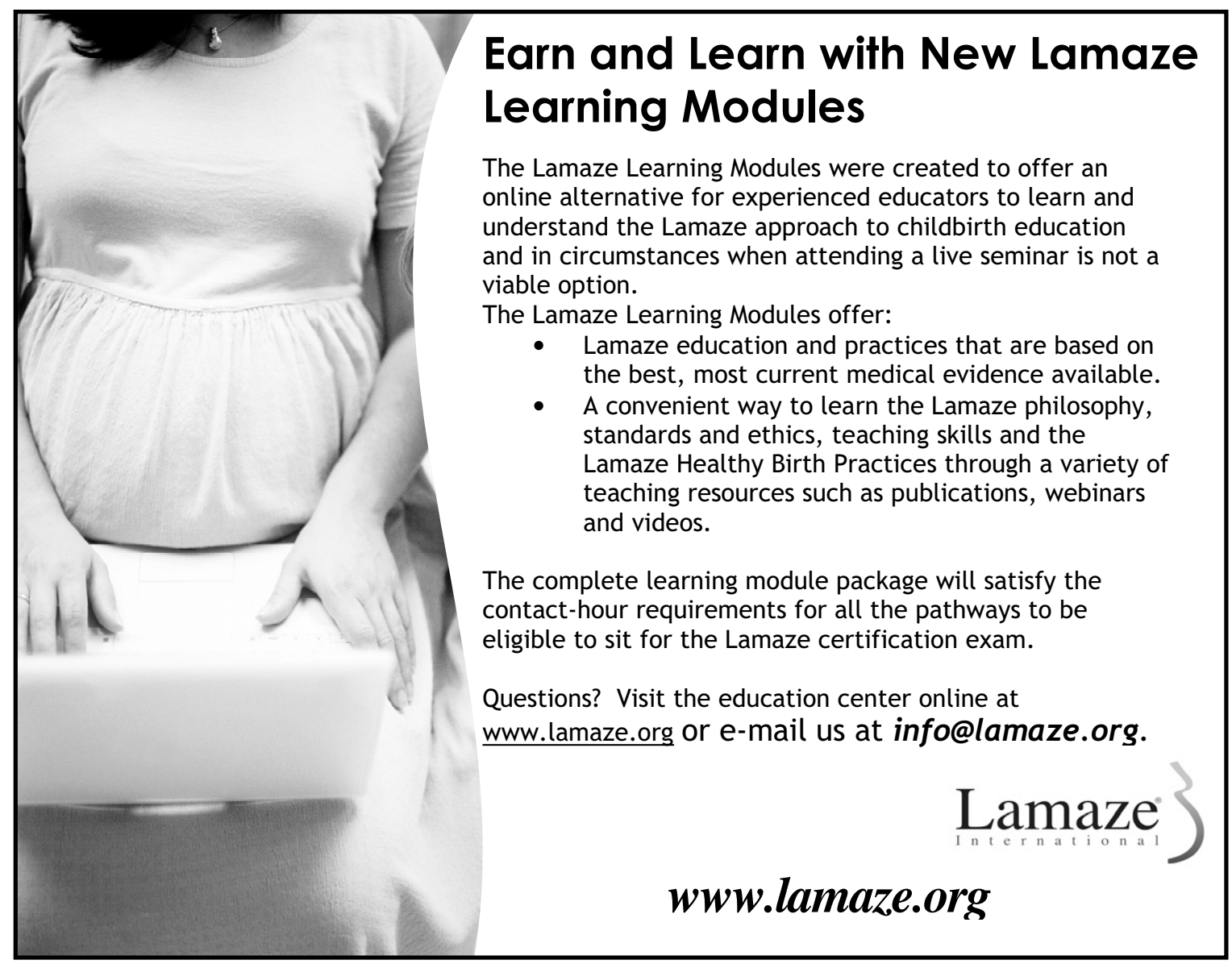

